\title{
Dampak Perubahan Perilaku Mahasiswa dalam Pembelajaran Daring
}

\author{
Ega Riski Suci Cahyani ${ }^{1}$, Khusnul Khotimah ${ }^{1}$, Risca Agustin², Ardina Eka \\ Nawang Sari ${ }^{1}$, Alfisyahrina Hapsery ${ }^{1^{*}}$ \\ ${ }^{1}$ Author Statistika, Universitas PGRI Adi Buana Surabaya, Indonesia \\ ${ }^{2}$ Pendidikan Guru Sekolah Dasar, Universitas PGRI Adi Buana Surabaya, Indonesia \\ *Corresponding author: alfisyahrina@unipasby.ac.id
}

Received: 22 September 2021 Accepted: 27 September 2021

\begin{abstract}
Kebijakan system pembelajaran daring dalam Rangka Pencegahan Penyebaran COVID-19 menuntut mahasiswa untuk segera beradaptasi dengan berbagai macam bantuan teknologi yang telah berkembang cukup pesat di era saat ini. Interaksi mahasiswa dan dosen menjadi berkurang, begitu juga antar mahasiswa yang semakin susah untuk saling berdiskusi. Interaksi dan perilaku sosial yang efektif akan memberikan dampak terhadap proses pembelajaran yang efektif pula. Sehingga untuk mengetahui pengaruh perubahan perilaku sosial mahasiswa terhadap efektifitas pembelajaran di tengah pandemi, perlu dilakukan kajian guna menciptakan sistem pembelajaran yang lebih efektif, nyaman, dan efisien. Salah satu metode yang dapat digunakan untuk mengetahui pengaruh tersebut yaitu dengan analisis regresi logistik biner. Analisis regresi logistik biner merupakan salah satu metode yang dapat menggambarkan hubungan antara variabel respon (berskala biner yaitu mempunyai dua kategori) dan variabel independennya. Hasil penelitian diperoleh bahwa $85 \%$ dari mahasiswa yang dijadikan sebagai sampel penelitian merasa bahwa pembelajaran daring sudah efektif pelaksanaannya. Diperoleh variabel yang berpengaruh signifikan terhadap efektifitas pembelajaran adalah variabel Interaksi dengan Mahasiswa dan variabel Perilaku Belajar. Hasil penelitian menunjukkan bahwa mahasiswa akan berpeluang mengalami pembelajaran yang efektif sebesar $99,98 \%$ apabila mengalami perubahan positif terhadap interaksi antar mahasiswa dan perubahan positif terhadap perilaku belajarnya selama pembelajaran daring.

Keywords- Regresi Logistik, Perubahan Perilaku, Pembelajaran Daring.
\end{abstract}

\section{PENDAHULUAN}

Perkembangan kasus penyebaran COVID-19 di Indonesia yang tak kunjung menurun, mendorong pemerintah Indonesia untuk melakukan upaya pencegahan perkembangan dan penyebaran virus ini. Begitupun pada sektor pendidikan yang juga terkena imbasnya, dibutuhkan kebijakan khusus yang tidak hanya sebagai upaya dalam pencegahan namun juga terkait pelaksanaan proses belajar mengajar di seluruh jenjang pendidikan yang seharusnya tetap berjalan. Sehingga diambil kebijakan yang tertuang dalam Surat Edaran Mendikbud Nomor 3 Tahun 2020 [1] tentang Pencegahan COVID-19 pada Satuan Pendidikan, dan Nomor 36962/MPK.A/HK/2020 tentang Pembelajaran secara Daring dan Bekerja dari Rumah dalam Rangka Pencegahan Penyebaran Corona Virus Disease (COVID-19), Surat Edaran Nomor 4 Tahun 2020 [2]Menteri Pendidikan dan Kebudayaan Nadiem Anwar Makarim tentang pelaksanaan pendidikan dalam masa darurat COVID-19, serta Surat Edaran dan petunjuk dari Kepala Daerah. Sistem pembelajaran tersebut dilakukan dari rumah tanpa tatap muka secara langsung, melainkan dilakukan dengan sistem Pembelajaran Jarak Jauh (PJJ) atau pembelajaran dengan sistem daring (dalam jaringan) atau online.

Kebijakan tersebut menuntut pelajar/mahasiswa untuk segera beradaptasi dengan sistem pembelajaran daring menggunakan berbagai macam bantuan teknologi yang telah berkembang cukup pesat di era saat ini. Upaya adaptasi ini harus diimbangi dengan pengawasan, bimbingan dan dukungan, baik secara fisik maupun psikis untuk memaksimalkan dampak positif yang dapat diperoleh serta meminimalisir dampak negatif yang akan ditimbulkan, seperti kendala-kendala dalam penyesuaian terhadap sistem pembelajaran yang terbilang masih baru tersebut. Dampak positif proses pembelajaran seperti ini diantaranya yaitu membentuk sifat disiplin secara mental dan formal, memberikan kemudahan bagi penguatan, proses penilaian oleh dosen menjadi lebih optimal, serta interaksi antar mahasiswa atau perserta didik dapat secara langsung diamati oleh dosen terutama dalam proses menerima/mendengarkan materi [3]. Tak hanya dampak positif, dampak negatif pun juga dirasakan oleh mahasiswa maupun dosen seperti proses perkuliahan membosankan, pembelajaran daring yang kaku dan klasik, serta pembejalaran yang hanya berlaku satu arah (monoton) menciptakan peluang untuk menurunnya daya kreativitas serta inovasi [4]. Selain itu interaksi mahasiswa dan dosen menjadi berkurang, begitu juga antar mahasiswa yang semakin susah untuk saling berdiskusi.

Dengan kelemahan yang telah disebutkan, menimbulkan berbagai pertanyaan seperti sudahkah sistem pembelajaran di masa pandemi efektif, adakah dampak dari perubahan perilaku sosial yang ditimbulkan. Interaksi dan perilaku sosial yang efektif akan memberikan dampak terhadap proses pembelajaran yang efektif pula. Sehingga untuk mengetahui pengaruh perubahan perilaku sosial mahasiswa terhadap efektifitas pembelajaran di tengah pandemi, perlu dilakukan kajian guna menciptakan sistem pembelajaran yang lebih efektif, nyaman, dan efisien [5]. Salah satu metode yang dapat digunakan untuk mengetahui pengaruh tersebut yaitu dengan analisis regresi logistic biner. Analisis regresi logistik biner merupakan salah satu metode yang dapat menggambarkan hubungan antara variabel respon (berskala biner yaitu mempunyai dua kategori) dan variabel independennya, selain itu manfaat dari analisis ini yaitu dapat digunakan untuk mengetahui seberapa besar pengaruh perubahan perilaku sosial mahasiswa terhadap efektifitas pembelajaran daring yang kedepannya dapat berguna untuk membantu meningkatkan kualitas sistem pendidikan 
Indonesia di masa pandemi. Berdasarkan uraian latar belakang diatas, maka permasalahan yang dirumuskan pada penelitian ini yaitu bagaimana dampak perubahan perilaku mahasiswa Surabaya terhadap efektifitas pembelajaran di tengah pandemi.

\section{METODE PENELITIAN}

\section{A. Sumber Data}

Data yang digunakan dalam penelitian ini adalah data primer yang merupakan data hasil survei penyebaran kuesioner. Dalam penelitian ini yang menjadi populasi adalah seluruh mahasiswa perguruan tinggi yang ada di Kota Surabaya. Sedangkan Penetapan sampel yang digunakan dalam penelitian ini menggunakan jenis teknik NonProbability Sampling yang merupakan teknik penarikan sampel yang tidak memberikan peluang atau kesempatan yang sama bagi anggota populasi untuk terpilih menjadi sampel. Dengan metode gabungan Sampling kuota dan Sampling Insidential. Teknik pengumpulan data pada penelitian ini yaitu dengan cara penyebaran kuesioner online berbentuk google form pada mahasiswa yang perguruan tinggi yang ada di Kota Surabaya.

\section{B. Variabel Penelitian}

Variabel yang digunakan dalam penelitian ini terdiri dari 1 variabel dependen dan 8 variabel independen. Adapun variabel respon dan variabel independen yang digunakan akan dijelaskan pada Tabel 1.

\begin{tabular}{|c|l|c|}
\hline No & \multicolumn{1}{|c|}{ Variabel 1 Variabel Penelitian } & Skala Pengukuran \\
\hline 1. & Efektivitas Pembelajaran $(\mathrm{Y})$ & Nominal \\
\hline 2. & Kepatuhan Protokol Kesehatan $\left(\mathrm{X}_{1}\right)$ & Nominal \\
\hline 3. & Interaksi antar Mahasiswa $\left(\mathrm{X}_{2}\right)$ & Nominal \\
\hline 4. & Interaksi dengan Dosen $\left(\mathrm{X}_{3}\right)$ & Nominal \\
\hline 5. & Interaksi dengan Keluarga $\left(\mathrm{X}_{4}\right)$ & Nominal \\
\hline 6. & Interaksi dengan Masyarakat $\left(\mathrm{X}_{5}\right)$ & Nominal \\
\hline 7. & Perilaku Belajar $\left(\mathrm{X}_{6}\right)$ & Nominal \\
\hline 8. & Status Pekerjaan $\left(\mathrm{X}_{7}\right)$ & Nominal \\
\hline
\end{tabular}

\section{Langkah Penelitian}

Kerangka pikir yang akan digunakan dalam penelitian ini secara garis besar akan disajikan pada diagram alir berikut: Langkah penelitian yang digunakan adalah langkah analisis regresi logistik biner. Dengan tahapan sebagai berikut.

1. Mengumpulkan data dengan menyebarkan kuesioner penelitian.

2. Melakukan uji validitas dan reliabilitas pada data perubahan perilaku sosial mahasiswa Surabaya.

3. Mendeskripsikan data menggunakan statistika deskriptif untuk mengetahui karakteristik data.

4. Menguji independensi untuk mengetahui hubungan antara variabel dependen dengan variabel independennya.

5. Melakukan analisis regresi logistik biner.

a. Melakukan uji signifikansi parameter secara serentak.

b. Melakukan uji signifikansi parameter secara parsial.

c. Melakukan intepretasi terhadap model regresi logistik biner dan nilai odds ratio yang diperoleh..

d. Melakukan uji kesesuaian model.

6. Menarik kesimpulan dan saran.

\section{HASIL DAN PEMBAHASAN}

\section{A. Uji Validitas dan Reliabilitas}

Uji Validitas dilakukan untuk mengetahui keadaan yang menggambarkan tingkat instrumen yang bersangkutan mampu mengukur apa yang akan diukur mengenai efektifitas pembelajaran daring. Berikut merupakan hasil uji validitas dengan jumlah sampel sebanyak 50 responden.

Ho: Hasil pengukuran tidak valid

H1: Hasil pengukuran valid

Daerah Penolakan: Tolak Ho jika $r_{\text {hitung }}>r_{(50-2,0.05)}$

Berdasarkan pengujian validitas pada Tabel 2, menunjukkan bahwa terdapat variabel yang tidak valid, diantaranya yaitu variabel $\mathrm{X}_{17}$, dan $\mathrm{X}_{55}$. Sehingga untuk melakukan analisis selanjutnya perlu diatasi dengan tidak menggunakan variabel yang tidak valid. 
Tabel 2. Hasil Uji Validitas

\begin{tabular}{|c|c|c|c|c|c|c|c|c|c|}
\hline Variabel & $r_{\text {hitung }}$ & $r_{(50-2,0.05)}$ & Keputusan & Kesimpulan & Variabel & $r_{\text {hitung }}$ & $r_{(50-2,0.05)}$ & Keputusan & Kesimpulan \\
\hline $\mathrm{X}_{11}$ & 0.7704 & 0.2787 & Tolak $\mathrm{H}_{0}$ & Valid & $\mathrm{X}_{51}$ & 0.7030 & 0.2787 & Tolak $\mathrm{H}_{0}$ & Valid \\
\hline $\mathrm{X}_{12}$ & 0.8683 & 0.2787 & Tolak $\mathrm{H}_{0}$ & Valid & $X_{52}$ & 0.5990 & 0.2787 & Tolak $\mathrm{H}_{0}$ & Valid \\
\hline $\mathrm{X}_{13}$ & 0.7052 & 0.2787 & Tolak Ho & Valid & $X_{53}$ & 0.7032 & 0.2787 & Tolak $\mathrm{H}_{0}$ & Valid \\
\hline$X_{14}$ & 0.8441 & 0.2787 & Tolak $\mathrm{H}_{0}$ & Valid & $X_{54}$ & 0.7324 & 0.2787 & Tolak $\mathrm{H}_{0}$ & Valid \\
\hline $\mathrm{X}_{15}$ & 0.8848 & 0.2787 & Tolak $\mathrm{H}_{0}$ & Valid & $X_{55}$ & 0.1755 & 0.2787 & $\begin{array}{c}\text { Gagal } \\
\text { Tolak Ho }\end{array}$ & Tidak Valid \\
\hline $\mathrm{X}_{16}$ & 0.8204 & 0.2787 & Tolak $\mathrm{H}_{0}$ & Valid & $X_{56}$ & 0.6987 & 0.2787 & Tolak $\mathrm{H}_{0}$ & Valid \\
\hline $\mathrm{X}_{17}$ & $\begin{array}{c}- \\
0.1285\end{array}$ & 0.2787 & $\begin{array}{c}\text { Gagal } \\
\text { Tolak Ho }\end{array}$ & Tidak Valid & $X_{57}$ & 0.8034 & 0.2787 & Tolak $\mathrm{H}_{0}$ & Valid \\
\hline $\mathrm{X}_{21}$ & 0.8226 & 0.2787 & Tolak $\mathrm{H}_{0}$ & Valid & $X_{61}$ & 0.8397 & 0.2787 & Tolak $\mathrm{H}_{0}$ & Valid \\
\hline $\mathrm{X}_{22}$ & 0.7862 & 0.2787 & Tolak $\mathrm{H}_{0}$ & Valid & $\mathrm{X}_{62}$ & 0.8587 & 0.2787 & Tolak $\mathrm{H}_{0}$ & Valid \\
\hline $\mathrm{X}_{23}$ & 0.7796 & 0.2787 & Tolak $\mathrm{H}_{0}$ & Valid & $\mathrm{X}_{63}$ & 0.8987 & 0.2787 & Tolak $\mathrm{H}_{0}$ & Valid \\
\hline $\mathrm{X}_{24}$ & 0.4259 & 0.2787 & Tolak $\mathrm{H}_{0}$ & Valid & $\mathrm{X}_{64}$ & 0.7501 & 0.2787 & Tolak $\mathrm{H}_{0}$ & Valid \\
\hline $\mathrm{X}_{25}$ & 0.2768 & 0.2787 & $\begin{array}{c}\text { Gagal } \\
\text { Tolak Ho }\end{array}$ & Valid & $\mathrm{X}_{65}$ & 0.7745 & 0.2787 & Tolak $\mathrm{H}_{0}$ & Valid \\
\hline $\mathrm{X}_{26}$ & 0.6764 & 0.2787 & Tolak $\mathrm{H}_{0}$ & Valid & $\mathrm{X}_{66}$ & 0.6741 & 0.2787 & Tolak $\mathrm{H}_{0}$ & Valid \\
\hline $\mathrm{X}_{27}$ & 0.7824 & 0.2787 & Tolak $\mathrm{H}_{0}$ & Valid & $X_{67}$ & 0.7823 & 0.2787 & Tolak $\mathrm{H}_{0}$ & Valid \\
\hline$X_{31}$ & 0.6594 & 0.2787 & Tolak $\mathrm{H}_{0}$ & Valid & $X_{71}$ & 0.6008 & 0.2787 & Tolak $\mathrm{H}_{0}$ & Valid \\
\hline $\mathrm{X}_{32}$ & 0.5870 & 0.2787 & Tolak $\mathrm{H}_{0}$ & Valid & $\mathrm{X}_{72}$ & 0.8380 & 0.2787 & Tolak $\mathrm{H}_{0}$ & Valid \\
\hline $\mathrm{X}_{33}$ & 0.7253 & 0.2787 & Tolak $\mathrm{H}_{0}$ & Valid & $X_{73}$ & 0.8285 & 0.2787 & Tolak $\mathrm{H}_{0}$ & Valid \\
\hline $\mathrm{X}_{34}$ & 0.7077 & 0.2787 & Tolak $\mathrm{H}_{0}$ & Valid & $X_{74}$ & 0.8019 & 0.2787 & Tolak $\mathrm{H}_{0}$ & Valid \\
\hline $\mathrm{X}_{35}$ & 0.7242 & 0.2787 & Tolak $\mathrm{H}_{0}$ & Valid & $\mathrm{X}_{75}$ & 0.7855 & 0.2787 & Tolak $\mathrm{H}_{0}$ & Valid \\
\hline$X_{36}$ & 0.7609 & 0.2787 & Tolak $\mathrm{H}_{0}$ & Valid & $X_{76}$ & 0.7123 & 0.2787 & Tolak $\mathrm{H}_{0}$ & Valid \\
\hline $\mathrm{X}_{37}$ & 0.7829 & 0.2787 & Tolak $\mathrm{H}_{0}$ & Valid & $X_{77}$ & 0.7870 & 0.2787 & Tolak $\mathrm{H}_{0}$ & Valid \\
\hline$X_{41}$ & 0.8932 & 0.2787 & Tolak $\mathrm{H}_{0}$ & Valid & $\mathrm{Y}_{1}$ & 0.5781 & 0.2787 & Tolak $\mathrm{H}_{0}$ & Valid \\
\hline$X_{42}$ & 0.9163 & 0.2787 & Tolak $\mathrm{H}_{0}$ & Valid & $\mathrm{Y}_{2}$ & 0.6581 & 0.2787 & Tolak $\mathrm{H}_{0}$ & Valid \\
\hline $\mathrm{X}_{43}$ & 0.9049 & 0.2787 & Tolak $\mathrm{H}_{0}$ & Valid & $\mathrm{Y}_{3}$ & 0.8432 & 0.2787 & Tolak $\mathrm{H}_{0}$ & Valid \\
\hline $\mathrm{X}_{44}$ & 0.5967 & 0.2787 & Tolak $\mathrm{H}_{0}$ & Valid & $\mathrm{Y}_{4}$ & 0.7057 & 0.2787 & Tolak $\mathrm{H}_{0}$ & Valid \\
\hline $\mathrm{X}_{45}$ & 0.6597 & 0.2787 & Tolak $\mathrm{H}_{0}$ & Valid & $Y_{5}$ & 0.8795 & 0.2787 & Tolak $\mathrm{H}_{0}$ & Valid \\
\hline$X_{46}$ & 0.4135 & 0.2787 & Tolak $\mathrm{H}_{0}$ & Valid & $\mathrm{Y}_{6}$ & 0.8736 & 0.2787 & Tolak $\mathrm{H}_{0}$ & Valid \\
\hline $\mathrm{X}_{47}$ & 0.4053 & 0.2787 & Tolak $\mathrm{H}_{0}$ & Valid & $\mathrm{Y}_{7}$ & 0.8410 & 0.2787 & Tolak $\mathrm{H}_{0}$ & Valid \\
\hline
\end{tabular}

Pemeriksaan reliabilitas dilakukan untuk menunjukkan hasil pengukuran dapat dipercaya dan dapat diandalkan. Berikut merupakan hasil pemeriksaan reliabilitas dengan jumlah sampel sebanyak 50 responden. Tabel 3. Hasil Pemeriksaan Reliabilitas

\begin{tabular}{|c|c|}
\hline Variabel & Cronbach's Alpha \\
\hline Kepatuhan Protokol Kesehatan $\left(\mathrm{X}_{1}\right)$ & 0.92 \\
\hline Interaksi antar Mahasiswa $\left(\mathrm{X}_{2}\right)$ & 0.83 \\
\hline Interaksi dengan Dosen $\left(X_{3}\right)$ & 0.83 \\
\hline Interaksi dengan Keluarga $\left(\mathrm{X}_{4}\right)$ & 0.83 \\
\hline Interaksi dengan Masyarakat $\left(X_{5}\right)$ & 0.82 \\
\hline Perilaku Belajar $\left(X_{6}\right)$ & 0.91 \\
\hline Status Pekerjaan $\left(X_{7}\right)$ & 0.87 \\
\hline Efektifitas Pembelajaran (Y) & 0.89 \\
\hline
\end{tabular}

Tabel 3 memberi informasi bahwa nilai reliabilitas dari keseluruhan sangat reliabel yaitu lebih dari 0,81 dan handal untuk digunakan pada analisis selanjutnya.

\section{B. Karakteristik Variabel Penelitian}

Penelitian mengenai dampak perubahan perilaku mahasiswa dalam pembelajaran daring ini menggunakan variabel respon yang bersifat biner, yaitu Pembelajaran yang Efektif dan Pembelajaran yang Tidak Efektif. Sedangkan variabel prediktor yang digunakan adalah 7 faktor yang diduga berpengaruh terhadap Efektifitas Pembelajaran. Variabel respon pada penelitian ini adalah Efektivitas Pembelajaran yang disajikan pada Gambar 1 berikut. 


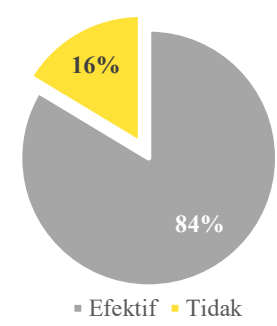

Gambar 1. Karakteristik Variabel Efektifitas Pembelajaran

Berdasarkan Gambar 1 diperoleh bahwa 84\% mahasiswa yang merasa bahwa pembelajaran daring sudah efektif pelaksanaannya. Diagram tersebut menunjukkan bahwa data yang digunakan pada penelitian ini tidak balance.

Faktor-faktor yang diduga memiliki pengaruh terhadap Efektifitas Pembelajaran Daring adalah Kepatuhan Protokol Kesehatan (X1), Interaksi antar Mahasiswa (X2), Interaksi dengan Dosen (X3), Interaksi dengan Keluarga (X4), Interaksi dengan Masyarakat (X5), Perilaku Belajar (X6) dan Status Pekerjaan (X7).

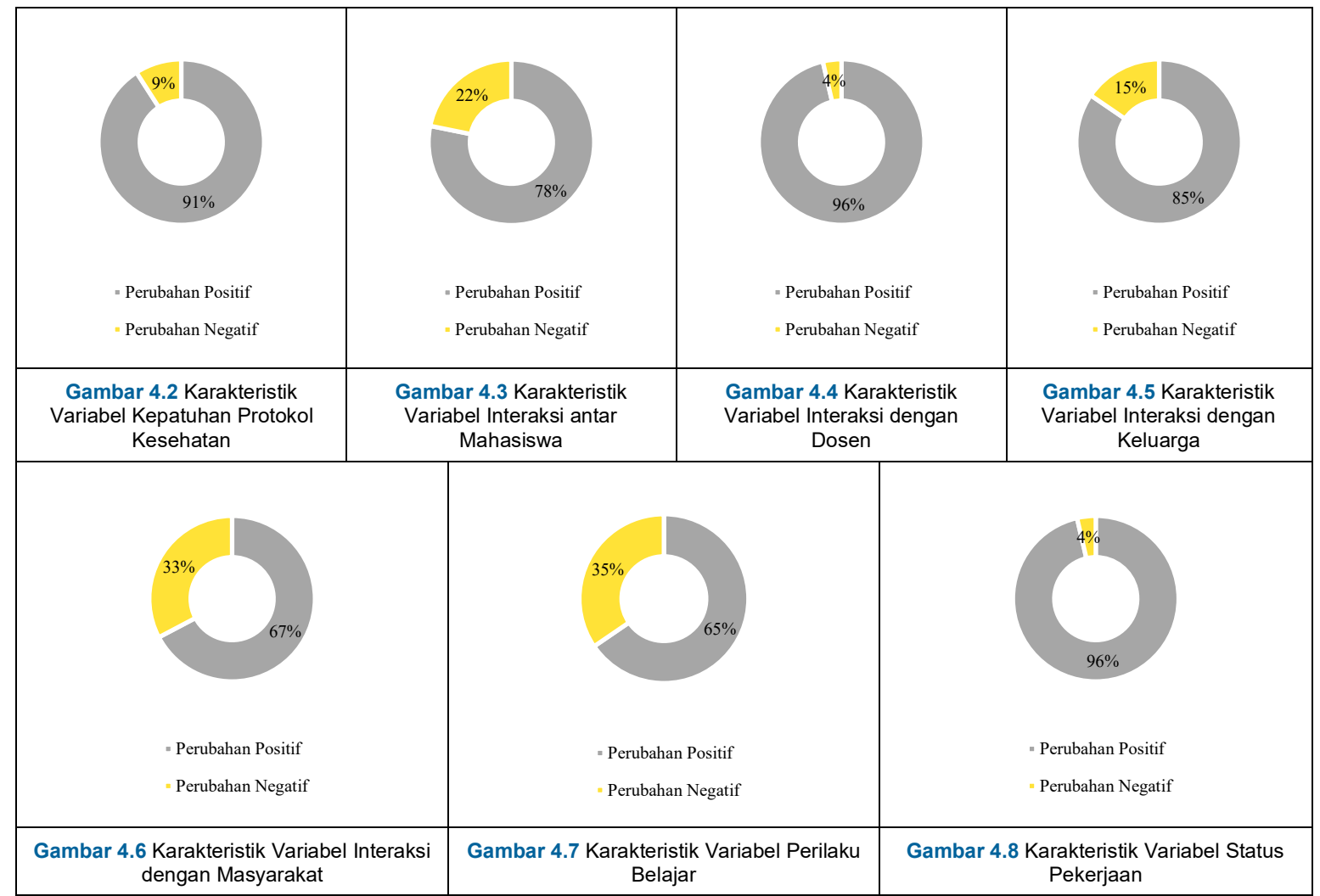

\section{Uji Independensi}

Selanjutnya, dilakukan uji independensi untuk mengetahui hubungan antara variabel respon dengan variabel prediktor.

$H_{0}$ : Tidak ada hubungan antara dua variabel yang diamati yaitu varibel dependen $(\mathrm{Y})$ dengan variabel independen $(\mathrm{X})$ $H_{1}$ : Terdapat hubungan antara dua variabel yang diamati yaitu varibel dependen $(\mathrm{Y})$ dengan variabel independen $(\mathrm{X})$

\begin{tabular}{|c|c|c|c|}
\hline Variabel Prediktor & Chi-Square & P-value & Keputusan \\
\hline Kepatuhan Protokol Kesehatan $\left(\mathrm{X}_{1}\right)$ & 2.7915 & 0.0948 & Gagal Tolak $\mathrm{H}_{0}$ \\
\hline Interaksi antar Mahasiswa $\left(\mathrm{X}_{2}\right)$ & 12.093 & 0.0005 & Tolak $\mathrm{H}_{0}$ \\
\hline Interaksi dengan Dosen $\left(\mathrm{X}_{3}\right)$ & $4.2215 \times 10^{-30}$ & 1 & Gagal Tolak $\mathrm{H}_{0}$ \\
\hline Interaksi dengan Keluarga $\left(\mathrm{X}_{4}\right)$ & 0.8353 & 0.3607 & Gagal Tolak $\mathrm{H}_{0}$ \\
\hline Interaksi dengan Masyarakat $\left(\mathrm{X}_{5}\right)$ & 0.7812 & 0.3768 & Gagal Tolak $\mathrm{H}_{0}$ \\
\hline Perilaku Belajar $\left(\mathrm{X}_{6}\right)$ & 15.577 & $7.922 \times 10^{-05}$ & Tolak $\mathrm{H}_{0}$ \\
\hline Status Pekerjaan $\left(\mathrm{X}_{7}\right)$ & $4.2215 \times 10^{-30}$ & 1 & Gagal Tolak $\mathrm{H}_{0}$ \\
\hline
\end{tabular}


Hasil uji Independensi pada Tabel 3 menunjukkan bahwa adanya hubungan antara variabel Efektivitas Pembelajaran (Y) dengan variabel Interaksi antar Mahasiswa $\left(\mathrm{X}_{2}\right)$ dan Perilaku Belajar $\left(\mathrm{X}_{6}\right)$. Hal ini dapat dilihat dari nilai p-value kurang dari $\alpha(0,05)$ yang berarti tolak $\mathrm{H}_{0}$.

\section{Analisis Regresi Logistik Biner}

(1) Estimasi Parameter

Koefisien parameter model regresi diestimasi menggunakan Maximum Likelihood Estimation. Hasil estimasi parameter dapat dilihat pada Tabel 4 berikut.

Tabel 4. Hasil Pengujian Estimasi Parameter

\begin{tabular}{|l|r|r|}
\hline \multicolumn{1}{|c|}{ Parameter } & Koefisien & \multicolumn{1}{c|}{ P-Value } \\
\hline (Intercept) & -0.1742 & 0.9381 \\
\hline Kepatuhan Protokol Kesehatan $\left(\mathrm{X}_{1}\right)$ & 0.6339 & 0.5732 \\
\hline Interaksi antar Mahasiswa $\left(\mathrm{X}_{2}\right)$ & -2.1437 & 0.0057 \\
\hline Interaksi dengan Dosen $\left(\mathrm{X}_{3}\right)$ & 0.8264 & 0.5493 \\
\hline & & \\
\hline Interaksi dengan Keluarga $\left(\mathrm{X}_{4}\right)$ & 1.2437 & 0.3296 \\
\hline Interaksi dengan Masyarakat $\left(\mathrm{X}_{5}\right)$ & -0.3867 & 0.5766 \\
\hline Perilaku Belajar $\left(\mathrm{X}_{6}\right)$ & -2.5246 & 0.0007 \\
\hline Status Pekerjaan $\left(\mathrm{X}_{7}\right)$ & -0.6097 & 0.6643 \\
\hline
\end{tabular}

Dengan menggunakan tingkat kesalahan 5\% dan taraf signifikansi 95\% pada proses eliminasi variabel, diketahui bahwa hanya terdapat 2 variabel yang signifikan, antara lain yaitu variabel Interaksi antar Mahasiswa $\left(X_{2}\right)$ dan Perilaku Belajar $\left(\mathrm{X}_{6}\right)$.

\section{(2) Uji Signifikansi Parameter}

\section{a. Uji Serentak}

Pengujian parameter dilakukan untuk menguji signifikansi koefisien $\beta$ dari model regresi yang telah diperoleh. Adapun pengujian parameter yang dilakukan adalah uji signifikansi secara serentak dan uji signifikansi secara individu.

$H_{0}: \beta_{1}=\beta_{2}=\beta_{3}=\beta_{4}=\beta_{5}=\beta_{6}=\beta_{7}=0$ (tidak ada pengaruh yang signifikan antara variabel prediktor terhadap variabel respon secara serentak).

$H_{1}$ : minimal ada satu $\beta_{j} \neq 0, \mathrm{j}=1,2, \ldots, 7$ (minimal ada satu variabel predictor yang berpengaruh yang signifikan terhadap variabel respon).

Daerah Kritis: tolak $H_{0}$ jika $G>\chi_{(0.05,7)}^{2}$ atau $p$-value $<\alpha$

Tabel 5. Hasil Pengujian Signifikansi Parameter Secara Serentak
\begin{tabular}{|c|r|r|r|r|}
\hline & $\mathrm{G}$ & $\mathrm{df}$ & $\chi_{(0.05,7)}^{2}$ & P-value \\
\hline $\begin{array}{l}\text { Likelihood } \\
\text { Ratio Test }\end{array}$ & 31.881 & 7 & 14.067 & $4.272 \times 10^{-05}$ \\
\hline
\end{tabular}

Berdasarkan uji Likelihood Ratio Test pada table 5 diketahui bahwa nilai G lebih besar dari Chi-Square table atau $p$ value kurang dari $\alpha(0,05)$. Maka diperoleh keputusan tolak $H_{0}$ yang artinya terdapat pengaruh yang signifikan antara variabel prediktor terhadap variabel respon secara serentak, atau minimal ada satu variabel prediktor yang berpengaruh signifikan terhadap evektifitas pembelajaran. Sehingga dapat dilakukan analisis selanjutnya yakni pengujian secara individu.

\section{b. Uji Individu}

Uji individu dilakukan untuk mengetahui variabel prediktor mana yang diduga berpengaruh signifikan terhadap variabel respon secara secara parsial. Hipotesis yang digunakan adalah sebagai berikut.

$H_{0}: \beta_{j}=0$ (tidak ada pengaruh yang signifikan antara variabel prediktor ke-j terhadap variabel respon)

$H_{1}: \beta_{j} \neq 0$ (terdapat pengaruh signifikan antara variabel prediktor ke- $j$ terhadap variabel respon) $\mathrm{j}=1,2, \ldots, 7$

Daerah Kritis : tolak $H_{0}$ jika $|W|>Z_{\alpha / 2}$ atau $p$-value $<\alpha$. 
Tabel 6. Hasil Pengujian Signifikansi Parameter Secara Individu

\begin{tabular}{|l|c|c|c|}
\hline \multicolumn{1}{|c|}{ Variabel } & Wald & P-value & Keputusan \\
\hline $\begin{array}{l}\text { Kepatuhan Protokol } \\
\text { Kesehatan }\left(\mathrm{X}_{1}\right)\end{array}$ & 0.5634 & 0.5744 & Gagal Tolak $\mathrm{H}_{0}$ \\
\hline Interaksi antar Mahasiswa $\left(\mathrm{X}_{2}\right)$ & 2.7618 & 0.0068 & Tolak $\mathrm{H}_{0}$ \\
\hline Interaksi dengan Dosen $\left(\mathrm{X}_{3}\right)$ & 0.5987 & 0.5507 & Gagal Tolak $\mathrm{H}_{0}$ \\
\hline $\begin{array}{l}\text { Interaksi dengan Keluarga } \\
\left(\mathrm{X}_{4}\right)\end{array}$ & 0.9750 & 0.3319 & Gagal Tolak $\mathrm{H}_{0}$ \\
\hline $\begin{array}{l}\text { Interaksi dengan Masyarakat } \\
\left(\mathrm{X}_{5}\right)\end{array}$ & 0.5583 & 0.5778 & Gagal Tolak $\mathrm{H}_{0}$ \\
\hline Perilaku Belajar $\left(\mathrm{X}_{6}\right)$ & 3.3774 & 0.0010 & Tolak $\mathrm{H}_{0}$ \\
\hline Status Pekerjaan $\left(\mathrm{X}_{7}\right)$ & 0.4339 & 0.6652 & Gagal Tolak $\mathrm{H}_{0}$ \\
\hline
\end{tabular}

Berdasarkan uji Wald pada Tabel 6 dapat diketahui bahwa variabel yang berpengaruh secara signifikan efektifitas pembelajaran daring adalah variabel Interaksi antar Mahasiswa $\left(X_{2}\right)$ dan Perilaku Belajar $\left(X_{6}\right)$, hal ini dikarenakan nilai wald pada masing-masing variabel tersebut lebih besar dari $Z_{0,05 / 2}(1,96)$ atau nilai $p$-value pada variabel tersebut lebih kecil dari $\alpha$. Sehingga memberikan keputusan tolak $H_{0}$. Sedangkan variabel yang tidak berpengaruh secara signifikan terhadap Efektivitas Pembelajaran adalah Kepatuhan Protokol Kesehatan $\left(X_{1}\right)$, Interaksi dengan Dosen $\left(X_{3}\right)$, Interaksi dengan Keluarga $\left(X_{4}\right)$, Interaksi dengan Masyarakat $\left(X_{5}\right)$, dan Status Pekerjaan $\left(X_{7}\right)$.

\section{(3) Seleksi Model Terbaik}

Pada pemodelan yang pertama, masih banyak variabel prediktor yang tidak signifikan terhadap target variabel, seleksi model terbaik dapat dilakukan untuk mengatasinya. Pada seleksi model terbaik menggunakan backward elimination, yaitu dengan mengeluarkan variabel prediktor yang tidak signifikan secara bertahap, sehingga diperoleh hasil sebagai berikut.

\begin{tabular}{|c|c|c|c|c|c|}
\hline \multirow{2}{*}{ Parameter } & \multirow{2}{*}{ Koefisien } & \multirow{2}{*}{$\begin{array}{c}P- \\
\text { Value }\end{array}$} & \multirow{2}{*}{$\begin{array}{l}\text { Odds } \\
\text { Ratio }\end{array}$} & \multicolumn{2}{|c|}{ Confidence Interval } \\
\hline & & & & Lower & Upper \\
\hline (Intercept) & 1.0457 & 0.0895 & 2.8455 & 0.9101 & 10.8493 \\
\hline $\begin{array}{c}\text { Interaksi } \\
\text { dengan } \\
\text { Mahasiswa } \\
\left(X_{22}\right)\end{array}$ & -2.222 & 0.0009 & 0.1084 & 0.026 & 0.3818 \\
\hline $\begin{array}{c}\text { Perilaku } \\
\text { Belajar }\left(X_{62}\right)\end{array}$ & -2.5236 & 0.0003 & 0.0802 & 0.0175 & 0.2812 \\
\hline
\end{tabular}

Setelah melakukan seleksi model terbaik dan diperoleh variabel yang berpengaruh signifikan terhadap efektifitas pembelajaran yakni variabel Interaksi dengan Mahasiswa $\left(\mathrm{X}_{2}\right)$ dan Perilaku Belajar $\left(\mathrm{X}_{6}\right)$, maka masing-masing variabel dapat dijelaskan berdasarkan nilai odds rasio yang diperoleh.

Nilai odds untuk variabel Interaksi dengan Mahasiswa $\left(\mathrm{X}_{2}\right)$ sebesar 0,1084, artinya mahasiswa yang mengalami perubahan positif dalam berinteraksi dengan mahasiswa lainnya, berpeluang memiliki pembelajaran yang efektif 0,1084 kali lebih besar dari pada mahasiswa yang mengalami perubahan negatif dalam berinteraksi dengan mahasiswa lainnya.

Nilai odds untuk variabel Perilaku Belajar $\left(\mathrm{X}_{6}\right)$ sebesar 0,0802, artinya mahasiswa yang mengalami perubahan positif dalam perilaku belajar, berpeluang memiliki pembelajaran yang efektif 0,0802 kali lebih besar dari pada mahasiswa yang mengalami perubahan negatif dalam perilaku belajarnya.

Variabel yang berpengaruh signifikan terhadap efektifitas pembelajaran yang telah diperoleh, dapat dibentuk suatu model yang dapat menjelaskan mengenai efektifitas pembelajaran daring di Kota Surabaya yang diberikan sebagai berikut.

dengan:

$$
\pi(x)=\frac{\exp (g(x))}{1+\exp (g(x))},
$$

$g(x)=1.0457-2.222$ interaksi dengan mahasiswa ${ }_{2}-2.5236$ perilaku belajar $_{2}$

$g(x)=1.0457-2.222(2)-2.5236(2)=-8.4455$ 


$$
\pi(x)=\frac{\exp (-8.4455)}{1+\exp (-8.4455)}=0.0002 .
$$

Perhitungan nilai $\pi(x)$ tersebut menunjukkan bahwa mahasiswa yang mengalami perubahan positif terhadap interaksi antar mahasiswa dan perubahan positif terhadap perilaku belajarnya berpeluang mengalami pembelajaran daring yang tidak efektif sebesar 0.0002. sedangkan peluang mengalami pembelajaran daring yang efektif sebesar 0.9998 yang diberikan oleh perhitungan sebagai berikut.

$$
1-\pi(x)=1-0.0002=0.9998 \text {. }
$$

(4) Uji Kesesuaian Model

Pengujian ini dilakukan untuk menguji apakah model efektifitas pembelajaran yang dihasilkan sudah sesuai, dengan kata lain tidak terdapat perbedaan antara hasil pengamatan dengan kemungkinan hasil prediksi model [6]. Pengujian kesesuaian model dilakukan menggunakan Hosmer-Lemeshow Goodness of Fit dengan hipotesis pengujian sebagai berikut.

$H_{0}$ : Model sesuai (tidak terdapat perbedaan yang signifikan antara hasil pengamatan dengan kemungkinan hasil prediksi model)

$H_{1}$ :Model tidak sesuai (terdapat perbedaan yang signifikan antara hasil pengamatan dengan kemungkinan hasil prediksi model)

Daerah Kritis: tolak $H_{0}$ jika nilai $\hat{C}$ lebih dari $\chi_{(g-2)}^{2}$ atau $p$-value $<\alpha$.

Tabel 8. Hasil Uji Kesesuaian Model

\begin{tabular}{|l|l|l|l|}
\hline & $\hat{C}$ & $\mathrm{df}$ & $P$-value \\
\hline Hosmer-Lemeshow & 0.3273 & 8 & 1 \\
\hline
\end{tabular}

Berdasarkan uji Hosmer Lemeshow pada Tabel 8 menunjukkan bahwa dengan menggunakan $\alpha=0.05$ diperoleh keputusan gagal tolak $H_{0}$ karena nilai $p$-value lebih besar dari $\alpha$. Sehingga dapat disimpulkan bahwa model telah sesuai.

\section{KESIMPULAN}

Berdasarkan hasil pernelitian menunjukkan bahwa variabel yang berpengaruh signifikan terhadap efektifitas pembelajaran yakni variabel Interaksi dengan Mahasiswa dan Perilaku Belajar. Dilihat dari nilai odds ratio yang diperoleh, diketahui bahwa mahasiswa yang mengalami perubahan positif dalam berinteraksi dengan mahasiswa lainnya, berpeluang memiliki pembelajaran yang efektif 0,1084 kali lebih besar dari pada mahasiswa yang mengalami perubahan negatif dalam berinteraksi dengan mahasiswa lainnya. Sedangkan mahasiswa yang mengalami perubahan positif dalam perilaku belajar, berpeluang memiliki pembelajaran yang efektif 0,0002 kali lebih besar dari pada mahasiswa yang mengalami perubahan negatif dalam perilaku belajarnya. Hasil penelitian juga diperoleh bahwa mahasiswa yang mengalami perubahan positif terhadap interaksi antar mahasiswa dan perubahan positif terhadap perilaku belajarnya berpeluang mengalami pembelajaran daring yang efektif sebesar 99,98\%.

\section{REFERENSI}

[1] Kemendikbud, "Surat Edaran Kemendikbud No. 3 Tahun 2020. Pencegahan Corona Virus Disease (COVID-19) Pada Satuan Pendidikan.," 2020.

[2] Kemendikbud, "Surat Edaran Kemendikbud No. 4 Tahun 2020. Pelaksanaan KebijakanPendidikan dalam Masa Darurat Penyebaran Corona Virus Disease Covid 19.," 2020.

[3] Z. D. Ulfa and U. Z. Mikdar, "Dampak Pandemi Covid-19 terhadap Perilaku Belajar, Sosial dan Kesehatan bagi Mahasiswa FKIP Universitas Palangka Raya," JOSSAE (Journal Sport Sci. Educ., vol. 5, no. 2, pp. 124-138, 2020.

[4] N. B. Argaheni, "Sistematik review: Dampak perkuliahan daring saat pandemi COVID-19 terhadap mahasiswa Indonesia," PLACENTUM J. Ilm. Kesehat. dan Apl., vol. 8, no. 2, pp. 99-108, 2020.

[5] B. Farah and R. D. Nasution, "Analisis perubahan orientasi pola hidup mahasiswa pasca berakhirnya masa pandemi covid19," J. Noken Ilmu-Ilmu Sos., vol. 5, no. 2, pp. 23-36, 2020.

[6] D. W. Hosmer Jr, S. Lemeshow, and R. X. Sturdivant, Applied logistic regression, vol. 398. John Wiley \& Sons, 2013. 